\title{
Incidence of Mite-Vectored Viruses of Wheat in the Texas High Plains and Interactions With Their Host and Vector
}

\author{
B. Bryan, L. Paetzold, F. Workneh ${ }^{\dagger}$, and C. M. Rush \\ Texas A\&M AgriLife Research, Bushland, TX 79012
}

\begin{abstract}
Mite-vectored virus diseases of wheat are common throughout the Great Plains and cause significant economic losses to growers each year. These diseases are caused by Wheat streak mosaic virus (WSMV), Triticum mosaic virus (TriMV), and Wheat mosaic virus (WMoV), all of which are transmitted by the wheat curl mite (WCM), Aceria tosichella Keifer. New wheat cultivars with tolerance or resistance to WSMV have been released recently, but their widespread cultivation and potential impact on mite-transmitted virus incidence in the Texas Panhandle was unknown. A total of 648 symptomatic wheat samples were collected from 26 counties, predominately in the Texas Panhandle, and tested by enzyme-linked immunosorbent assay (ELISA) for WSMV, TriMV, and WMoV. Samples that tested negative by ELISA were subsequently tested by realtime quantitative PCR (qPCR) for each virus. Approximately $93 \%$ of the samples tested by ELISA were positive for WSMV, 43\% were positive for TriMV, and 7\% were positive for WMoV. Eleven samples tested positive only for TriMV, but none were positive only for WMoV. When samples that tested negative for the different viruses by ELISA were retested by real-time qPCR, detection of each virus was significantly increased. When results of the ELISA test and qPCR were combined, $100 \%$ of the 648 samples tested positive for WSMV, approximately $94 \%$ were positive for TriMV, and $23 \%$ were positive for WMoV. This demonstrated that the incidence of TriMV in the Texas High Plains is much

by diagnostic laboratories in the Great Plains, should not be used for studies requiring a high degree of sensitivity and accuracy in virus detection. After initial virus infection status was determined, samples that tested positive for WSMV and TriMV were further observed for WCM infestation. A total of 292 samples were inspected and a total of 101 mites were collected from 40 tillers. Individual mites and the tillers from which they were recovered were tested by real-time qPCR to determine how copy numbers of WSMV and TriMV in mites and host tissue compared, and whether the WSMV/TriMV copy number ratio in individual mites was similar to that of the host tissue from which they were collected. In all mites and tillers tested, the WSMV copy number was always higher than that of TriMV and copy numbers of both viruses were always higher in plant tissue than in mites. Although there was a significant correlation between the WSMV/TriMV copy number ratio in plant tissue and in associated mites, the correlation coefficient was very low $(r=0.31, P=0.0248)$. In the majority of comparisons, the WSMV/TriMV ratio was higher in individual mites than in the tiller from which they were recovered. The reason for this increase is unknown but indicates that mites may preferentially acquire WSMV from tillers coinfected with WSMV and TriMV, a finding that could have significant implications for virus transmission and disease epidemiology.
\end{abstract} greater than previously reported. The fact that real-time qPCR revealed over a 2-fold increase in the incidence of TriMV and a 3-fold increase in WMoV demonstrated that the ELISA test, which is commonly used
Keywords: disease development and spread, pathogen detection, pathogen diversity
Hard red winter wheat is the major crop planted in Texas each year. In the 2016 to 2017 growing season, 4.7 million acres of wheat were planted, with over 68 million bushels produced representing more than $\$ 255$ million in revenue (U.S. Department of Agriculture National Agricultural Statistics Service 2017). The majority of wheat is grown in the Panhandle region where over 2 million acres produced more than 35 million bushels. With approximately $30 \%$ of wheat in this area under irrigation, the Panhandle region has the highest yields in the state. In this area, wheat production also benefits the cattle industry. Growing wheat as a dual-purpose crop to provide forage in the late fall and winter and grain in midsummer has become a common agricultural practice; in 2017, approximately half the wheat

${ }^{\dagger}$ Corresponding author: F. Workneh; f-workneh@tamu.edu

Funding: This project was partially supported by funding from the U.S. Department of Agriculture, Agriculture and Food Research Initiative (grant 2013-68004) and the Texas A\&M AgriLife Research Initiative on Plant Pathogens With Arthropod Vectors.

The author(s) declare no conflict of interest.

Accepted for publication 7 June 2019.

(C) 2019 The American Phytopathological Society grown in Texas was dual purpose. Dual-purpose wheat is typically planted early, from mid-August to early September, to maximize forage production. However, in so doing, farmers inadvertently expose the young wheat to increased pressure from insect pests and diseases.

In the Texas Panhandle and across the entire western Great Plains, mite-vectored virus diseases (MVVDs) are the predominant pathogenic constraint to economically sustainable wheat production (Burrows et al. 2009; Fuentes-Bueno et al. 2011). These diseases are especially problematic in dual-purpose wheat because it is planted early and exposed to high temperatures. Wheat streak mosaic virus (WSMV), Triticum mosaic virus (TriMV), and Wheat mosaic virus (WMoV) are the predominant pathogens in the MVVD complex and all are transmitted by the wheat curl mite (WCM), Aceria tosichella Keifer (Seifers et al. 1997, 2009). Historically, wheat streak mosaic (WSM) has been by far the most commonly encountered of all of the MVVDs in the region and has been recognized as a significant production constraint for years (Almas et al. 2016; Burrows et al. 2009; Velandia et al. 2010). TriMV was identified for the first time in Texas in 2008 and is usually present as a coinfection with WSMV (Burrows et al. 2009). WMoV or High Plains wheat mosaic virus, which is the least common of the three, was first identified from corn from the Texas Panhandle in 1993 and was soon identified in wheat throughout the western Great Plains (Rush and Michels 1996). 
There are currently no commercially available wheat cultivars with genetic resistance to all MVVDs, but several are resistant to WSMV (Graybosch et al. 2009; Haley et al. 2011; Mutti et al. 2011; Seifers et al. 2007). These include Mace, Snowmass, and RonL. Mace has the Wsml gene for resistance and Snowmass and RonL have Wsm2. Both genes are temperature sensitive, becoming ineffective for control of WSMV at temperatures above $24^{\circ} \mathrm{C}$ (Friebe et al. 2009; Seifers et al. 2006, 2013; Tatineni et al. 2016). Furthermore, if these cultivars become infected early in the season when temperatures are high, they do not recover later in the fall, even at temperatures at which the genetic resistance should be effective (Price et al. 2014). Cultivars with Wsml also have shown resistance to TriMV, but only at temperatures below $21^{\circ} \mathrm{C}$ (Byamukama et al. 2012; Friebe et al. 2009; Kumssa et al. 2017; Tatineni et al. 2010, 2016). The Wsm3 gene has demonstrated resistance to WSMV at temperatures up to $24^{\circ} \mathrm{C}$ and resistance to TriMV at 18 to $21^{\circ} \mathrm{C}$ (Liu et al. 2011; Kumssa et al. 2017). There are currently no commercial cultivars containing the Wsm3 gene. Because of the high temperatures in the Texas Panhandle during the planting period for dual-purpose wheat, the effectiveness of these resistance genes has been compromised and these cultivars are not commonly grown in this production region. The three main cultivars that were grown in the Texas Panhandle in 2017, and also widely grown throughout the southwestern Great Plains, were TAM 111, TAM 112, and TAM 113. These three accounted for $28.6,11.4$, and $4.1 \%$ of acreage, respectively (U.S. Department of Agriculture National Agricultural Statistics Service 2017). TAM 111 and TAM 113 are rated as moderately susceptible to WSMV (Texas Small Grains Variety Trials 2017). TAM 112 is rated as moderately resistant to WSMV (Texas Small Grains Variety Trials 2017), possessing genetic resistance to WCM (Dhakal et al. 2017; Liu et al. 2011; Price et al. 2014). However, the reaction of these cultivars to TriMV and WMoV has not been well documented. Other varieties that are widely grown in the Panhandle and Southwestern Great Plains include TAM 204, TAM 105, TAM 110, TAM 114, and Gallagher. Although several of these are rated as moderately resistant to WSMV (Texas Small Grains Variety Trials 2017), none have complete resistance to WSMV or any of the other mite-transmitted viruses. For this reason, it is prudent to routinely determine the relative incidence of these viruses in this major wheat production region.

The last comprehensive wheat survey for MVVD in Texas, along with eight other states in the Great Plains region, was conducted in 2008 (Burrows et al. 2009). A MVVD survey in four states of the Central Great Plains, which focused on TriMV, was conducted in 2010 and 2011 but did not include Texas (Byamukama et al. 2013). In the 2008 survey by Burrows et al. (2009), Texas had the highest incidence of all three viruses and the highest incidence of coinfections and triple infections. More than 50\% of samples tested positive for coinfections of WSMV and TriMV, 37\% tested positive for coinfections of WSMV and WMoV, and 26\% were positive for all three viruses. At that time, approximately $56 \%$ of all irrigated wheat acres were planted to TAM 105, 110, and 200, all of which were highly susceptible to all three mite-transmitted viruses. However, since the survey by Burrows et al. (2009), the most popular cultivars have changed significantly and many of the more widely grown cultivars now have moderate resistance to WSMV. Increased cultivation of varieties with resistance to WSMV could impact mite-vectored virus population dynamics and have the unintended consequence of increasing the incidence of TriMV and WMoV. To investigate this possibility, a study was conducted to provide a current profile of mite-vectored virus incidence in the Texas Panhandle. Because of the frequency of mixed infections and our interest in host-virus-vector interactions, we also determined the virus copy numbers of WSMV and TriMV in plant samples with mixed infections and in WCMs from the same plants as well as the WSMV/ TriMV copy number ratio.

\section{Materials and Methods}

Sample collection. A total of 648 wheat samples exhibiting symptoms of MVVD were collected from growers' fields from March through May 2017 and tested by enzyme-linked immunosorbent assay (ELISA) for WSMV, TriMV, and WMoV. The samples were collected from 194 fields in 26 Texas counties, mostly from the Panhandle region. However, some samples sent for diagnostic testing by farmers, county agents, crop consultants, and insurance adjustors represented counties outside the Panhandle. Although samples included in the study were submitted by a diverse group of clientele, the large majority were collected by the Bushland AgriLife team. An average of four samples were collected per field but varied from two to 12 , depending on the size of the field and incidence of symptomatic plants. Sampling sites within fields were arbitrarily chosen; however, wheat plants exhibiting typical symptoms of MVVD were specifically targeted for collection. Samples were returned to the laboratory the day they were collected and stored at $4{ }^{\circ} \mathrm{C}$ until processed. Approximately $0.2 \mathrm{~g}$ of symptomatic wheat leaf tissue from each sample was transferred to a 2-ml screw-cap tube (VWR, Sugarland, TX) containing a 5-mm steel grinding ball for future ELISA testing and for RNA extraction for real-time quantitative reverse transcription (qRT)-PCR testing. Tubed samples were stored at $-80^{\circ} \mathrm{C}$. The rest of the sample was stored in a plastic zip-top bag (Ziploc) at $4^{\circ} \mathrm{C}$ for subsequent WCM collection (see below).

Preliminary ELISA screening. Double antibody sandwich ELISA was performed to determine the presence of WSMV and WMoV in each sample, as described by Price et al. (2010). Indirect ELISA was performed to determine the presence of TriMV, using a slightly modified protocol of Seifers et al. (2008). All tubed samples were frozen in liquid nitrogen, homogenized using a Hard Tissue Grinder (VWR), and suspended in $750 \mu \mathrm{l}$ of sterile distilled deionized water. Polyvinyl chloride plates (Costar; Corning Inc., Kennebunk, ME) were used for all tests. Carbonate coating buffer (Agdia Inc., Elkhart, IN) was used to dilute samples. ECI buffer (Agdia) was used to dilute the WSMV and WMoV antivirus antibody (Agdia), the TriMV antisera (Seifers et al. 2008), and the antirabbit antibody alkaline phosphatase conjugate (Rockland, Limerick, PA). PNP (pnitrophenol) buffer and substrate tablets (Agdia) were used for plate color development. In accordance with the routine protocol of diagnostic laboratories in the Great Plains Diagnostic Network (GPDN), samples were considered positive if their absorbance value exceeded two times that of the negative control (Burrows et al. 2016).

Collection of WCMs. Individual WCMs were collected from infected tillers and tested by qRT-PCR for the presence of the various viral pathogens. This allowed comparison of virus profiles from mites and the specific tillers from which they were collected. Because of the large number of plant samples and the time required to collect individual mites, plants that initially tested positive for more than one virus by ELISA were prioritized when collecting WCMs. A total of 292 plant samples $(45 \%)$ were checked for mites, and at least four tillers per sample were inspected with a dissecting microscope for presence of mites. Single mites were collected and isolated on Flinders Technology Associates (FTA) cards (Whatman GE Healthcare, Pittsburgh, PA), similar to Price (2015). For improved visibility, the cards were prepared by making a light pencil mark where the mite would be placed. Single mites were collected using a single bristled artist's paintbrush. First, mites were transferred from the wheat leaf onto a triangle of black filter paper (Ahlstrom catalog number 8613) saturated with $70 \%$ ethanol. After several mites were collected, they were transferred to the FTA card and squashed into the membrane using a blunt probe. Next, approximately $0.1 \mathrm{~g}$ of host leaf tissue, from which the mites were collected, was placed into a 2-ml screw-cap tube (VWR) containing a 5-mm steel grinding ball for future RNA extraction. All implements were surface sterilized using alcohol and flame or a microincinerator (VWR). Mites were punched out of the FTA card using a sterilized Harris 2.00-mm micropunch (Whatman GE Healthcare) and ejected into 2-ml flip-top tubes (VWR) containing a 3-mm steel grinding ball. Mite and associated tissue samples were stored at $-80^{\circ} \mathrm{C}$.

Nucleic acid extraction and reverse transcription for wheat and mites. Total RNA was extracted from wheat leaf tissue using the Qiagen RNeasy Plant Mini Kit (Qiagen, Germantown, MD) per the manufacturer's instructions. The initial source from which 
RNA was extracted depended on whether WCMs had been collected from the plant. For samples with no WCMs collected (>93\%), total RNA was extracted from a $250-\mu l$ aliquot of the original sample processed for ELISA. For samples with WCMs, the host leaf tissue, from which mites were collected, was used. In this way, the virus profile in the mites could be directly related to the virus profile in the associated tiller.

Total RNA from individual WCMs was extracted using the Qiagen RNeasy Micro Kit per the manufacturer's instructions, but with a slight modification (Price 2015). One microliter of $5 \mathrm{ng} / \mu \mathrm{l}$ human 18s ribosomal RNA (Life Technologies Inc.) was included and served as an exogenous control. Minimum elution volume $(14 \mu \mathrm{l})$ was used to elute mite RNA.

Reverse transcription was performed using Qiagen's Omniscript RT kit and prescribed manufacturer's protocol. The only modification was with WCM RNA, in which the maximum recommended template RNA volume was used.

Real-time PCR analysis of wheat and mites. To confirm the accuracy of initial diagnostic tests, samples that were determined to be negative by ELISA were subjected to qRT-PCR analysis. Virus titers of WSMV, TriMV, and WMoV in wheat tissue and mites were determined using comparative quantification $(\Delta \Delta \mathrm{Ct})$ and were conducted using an Applied Biosystems ViiA 7 Real-Time PCR System (Applied Biosystems, Austin, TX). PCR amplification was done using a TaqMan Fast Advanced Master Mix kit (Applied Biosystems).

For the WSMV test, each reaction mix contained $1 \times$ TaqMan Fast Advanced Master Mix (Applied Biosystems), $0.3 \mu \mathrm{M}$ of forward primer Wsm F 9075, $0.3 \mu \mathrm{M}$ of reverse primer Wsm R 9196, and $0.25 \mu \mathrm{M}$ of Wsm P 9142 FAM-Probe (Tatineni et al. 2010). Eukaryotic 18S rRNA (VIC/MGB probe, primer limited; Applied Biosystems) was used as an endogenous control. Twenty nanograms of template cDNA was added to each reaction. Multiple plates were analyzed using the Expression Suite Software version 1.0.3 (ABI) plate study.doc function. For the TriMV test, reaction mix concentrations were the same as for the WSMV test. Forward primer Tri F 9754, reverse primer Tri R 9875, and Trip 9802 FAM-Probe (Tatineni et al. 2010) were used. The WMoV primers and probe were designed in our laboratory with the Thermo Fisher Custom TaqMan Assay Design Tool, using sequence accession number U60141 as follows: forward primer, HPV 402F (sequence 5'-CAAATTGGCAAT GAGTGCTGGTT-3'); reverse primer, HPV 496R (sequence 5'CAGCAGGAAAAATATCAAAGGTGTATTCAA-3'); and probe, HPV 430P (sequence FAM 5'-AAGGAGCACAAATATC-3' MGB-NFQ). The WMoV primers and probe can be requested from ABI (assay ID AP2W9G3, 20× Custom TaqMan Gene Expression Assay HPVP) and used $1 \times$ per reaction. The real-time PCR thermal cycling profile was the following default program: $95^{\circ} \mathrm{C}$ for $20 \mathrm{~s}$, followed by 40 cycles of denaturing at $95^{\circ} \mathrm{C}$ for $1 \mathrm{~s}$, then annealing at $60^{\circ} \mathrm{C}$ for $20 \mathrm{~s}$.

Conventional PCR testing for TriMV. The majority of plant disease diagnostic laboratories in the country have traditional PCR thermocyclers, but not all have ready access to a real-time thermocycler.
For this reason, conventional PCR was performed to compare results with those from ELISA and RT-qPCR tests. Thirty-six samples that tested negative for TriMV by ELISA but positive by quantitative reverse transcription PCR (RT-qPCR), along with three ELISApositive and three RT-qPCR-negative samples as controls, were tested by conventional PCR for the presence of TriMV using GoTaq Flexi DNA Polymerase (Promega, Madison, WI), following the protocol of Price (2015). Samples for this comparison were selected following sample analysis by qPCR and represented a range from low to high TriMV copy number.

Virus copy number determination. WSMV and TriMV virus copy numbers in leaf and mite samples were determined using plasmid DNA standards. Plasmid DNA for both viruses was synthesized by Invitrogen (Thermo Fisher, Pleasanton, CA). A 300-bp WSMV insert was synthesized from accession number NC001886 at position 9,001 to 9,300. A 300-bp TriMV insert was synthesized from accession number FJ669487 at position 9,661 to 9,960. The vector was commercial product pMA-T. The plasmid size was 2,674 bp. Sequence identity within the insertion sites was $100 \%$ as checked by Invitrogen. Approximately $5 \mu \mathrm{g}$ of plasmid DNA was synthesized. The web-based DNA Copy Number and Dilution Calculator (Thermo Fisher) was used to calculate copy number dilutions. A stock $0.5-\mathrm{ng} / \mu \mathrm{l}$ dilution was made with RNAse-free water, then standard serial dilutions of $10^{7}, 10^{6}, 10^{5} 10^{4}, 10^{3}, 10^{2}$, and 10 copies/ $\mu l$ were made. Standard curve quantification real-time tests were run on prepared standards and the reference sample to determine copy number per microliter of reference sample. All other unknown sample copy numbers were calculated by multiplying the reference copy number by the unknown sample's relative quantification value. To investigate the relationship between virus titers in the host and in associated WCM, copy number ratios of WSMV/TriMV in wheat and mite samples were determined.

Data analyses. Paired $t$ tests (PROC TTEST; SAS Institute, Cary, NC) were used to determine differences between copy numbers of WSM in individual leaves and mites, and similar analysis also was conducted for TriMV. Differences between copy numbers of WSMV and that of TriMV within individual leaves and mites were also similarly analyzed. In addition, differences between copy number ratios of WSMV and TriMV (WSM/TriMV) within individual leaves and mites or between individual leaves and mites in the same sample were similarly analyzed.

\section{Results}

Wheat ELISA results. A total of 648 plant samples were tested by ELISA. All three viruses were detected as double or triple infections, but only WSMV and TriMV were detected as single infections (Table 1). WSMV was the most pervasive virus and was detected in $93.8 \%$ of samples, either as single infections or in combination with TriMV and/or WMoV. TriMV and WMoV were detected in 42.7 and $7.3 \%$ of samples, respectively. Single virus infections of WSMV and TriMV occurred in 50.5 and $1.7 \%$ of samples, respectively. There were no single infections of WMoV. Coinfections of WSMV and TriMV as well as WSMV and WMoV occurred in

Table 1. Detection frequencies of Wheat streak mosaic virus (WSMV), Triticum mosaic virus (TriMV), and Wheat mosaic virus (WMoV) singly or in combinations in wheat samples using enzyme-linked immunosorbent assay (ELISA) and real-time PCR ${ }^{\mathrm{a}}$

\begin{tabular}{|c|c|c|c|c|c|c|c|c|}
\hline & $\begin{array}{l}\text { Overall } \\
\text { WSMV }\end{array}$ & $\begin{array}{l}\text { Overall } \\
\text { TriMV }\end{array}$ & $\begin{array}{l}\text { Overall } \\
\text { WMoV }\end{array}$ & $\begin{array}{c}\text { Only } \\
\text { WSMV }\end{array}$ & $\begin{array}{l}\text { Only } \\
\text { TriMV }\end{array}$ & $\underset{\text { TriMV }}{\text { WSMV + }}$ & $\begin{array}{l}\text { WSMV + } \\
\text { WMoV }\end{array}$ & $\begin{array}{c}\text { All three } \\
\text { viruses }\end{array}$ \\
\hline ELISA & 648 & 648 & 648 & 648 & 648 & 648 & 648 & 648 \\
\hline Positive & 608 & 277 & 47 & 327 & 11 & 234 & 15 & 32 \\
\hline$\%$ positive & 93.8 & 42.7 & 7.3 & 50.5 & 1.7 & 36.1 & 2.3 & 4.9 \\
\hline qRT-PCR ${ }^{b}$ & 40 & 371 & 601 & 40 & 371 & 382 & 601 & 601 \\
\hline Positive & 40 & 330 & 101 & 29 & 0 & 273 & 11 & 90 \\
\hline$\%$ positive & 100.0 & 88.9 & 16.8 & 72.5 & 0.0 & 71.5 & 1.8 & 15.0 \\
\hline $\begin{array}{l}\text { Overall ELISA } \\
\text { and qRT-PCR }\end{array}$ & 648 & 607 & 148 & 29 & 0 & 508 & 12 & 136 \\
\hline$\%$ positive & 100.0 & 93.7 & 22.8 & 4.5 & 0.0 & 78.4 & 1.9 & 21.0 \\
\hline
\end{tabular}

${ }^{a}$ Values are presented as the number of samples unless indicated otherwise. qRT-PCR = real-time quantitative reverse transcription PCR.

${ }^{b}$ All samples were initially tested by ELISA. Samples that were negative for a virus were then tested by real-time PCR. 
36.1 and $2.3 \%$ of samples, respectively. Triple infections occurred in $4.9 \%$ of samples. No coinfections of TriMV and WMoV were detected.

Wheat qRT-PCR results. Real-time PCR analysis of samples that tested negative by ELISA yielded dramatically different results than those obtained by the ELISA test (Table 1). As expected, realtime qPCR was much more sensitive and detected one or more of the three viruses in plants that tested negative for one or more of the viruses by ELISA. When results of the ELISA and qPCR tests were combined, WSMV was detected in $100 \%$ of the original 648 samples, TriMV was detected in $93.7 \%$ of samples (over twice that detected by ELISA alone), and WMoV was detected in $22.8 \%$ of samples (over three times that of the ELISA results). Single virus infections by WSMV were detected in only $4.5 \%$ of samples, mainly because TriMV detection was so high. Since WSMV was universally present, no single infections of TriMV or WMoV were detected. Coinfections of WSMV and TriMV were detected in 78.4\% of samples, over twice that indicated by ELISA. Because TriMV was so prevalent in samples, as determined by $\mathrm{qPCR}$, coinfections of WSMV and WMoV were detected in only $1.9 \%$ of samples. This was three times less than by ELISA, which failed to detect TriMV in samples with low virus titers as a result of its lack of sensitivity compared with qPCR. No coinfections by TriMV and WMoV were detected. Triple infections were detected in $21 \%$ of samples, four times more than by ELISA.

Single WCM and host tiller qRT-PCR results. After virus composition was determined in initial testing, a total of 292 samples that were coinfected, either by WSMV and TriMV, WSMV and WMoV, or all three viruses, were checked for mites. A total of $101 \mathrm{WCMs}$ were collected from 40 samples, representing 29 fields (Table 2). As expected, the frequency of WSMV detection in WCMs was similar to that in the host leaf from which they were collected. However, TriMV and WMoV were detected much less frequently in WCMs than in their associated host leaf (Table 2). Of the 40 tillers from which mites were collected, all were positive for WSMV and TriMV and $52.5 \%$ were positive for all three viruses. Of the 101 mites collected, four were negative for WSMV, 47 were positive for WSMV and TriMV, five were positive for WSMV and WMoV, and eight were positive for all three viruses.

Copy numbers of WSMV and TriMV were always significantly greater in plants than in mites $(t=24.8, P<0.0001$ and $t=16.7$, $P<0.0001$, respectively; $d f=99$ for both) and copy numbers of WSMV were always significantly higher than those of TriMV $(t=$ 14.7, $P<0.0001$ and $t=15.9, P<0.0001$, respectively; $d f=99$ for both) in both plants and mites (Table 3). However, the WSMV/ TriMV copy number ratio in mites was only weakly correlated to the WSMV/TriMV ratio in the leaf from which the mites were collected ( $r=0.31, P=0.0248$ ). Somewhat surprisingly, the WSMV/ TriMV copy number ratio was numerically higher in $77 \%$ of the individual mites (more WSMV in relation to TriMV) than in the corresponding leaf from which they were collected (Table 3). However, the difference, although consistent, was not significant, owing to the tremendous variability in copy numbers of the two viruses. In the instances in which the copy number ratio was lower in the mite than in the associated tiller, the copy number of TriMV in the tiller was always extremely low. WMoV was not included in this part of the study because plasmid DNA for WMoV was not available and therefore copy number was not determined.
Conventional PCR for detection of TriMV. Except in samples with very low virus titer, results obtained with conventional PCR corresponded well with those obtained with RT-qPCR. Of the 36 samples tested, TriMV was detected with conventional PCR in all but the eight samples (22.2\%) with the lowest qPCR Ct values. Real-time PCR samples with a $\mathrm{Ct}$ value $\leq 32$ reliably tested positive by conventional PCR. A sample with a qPCR Ct value of 34.2 was the highest that tested positive; above this value, all samples were negative. Results of conventional PCR on samples with qPCR Ct values of approximately 33 were variable probably as a result of several factors including sample quality.

\section{Discussion}

ELISA is currently the standard method used by diagnostic laboratories in the GPDN to detect and identify MVVDs of wheat. Typically, samples are considered positive if their absorbance value is two or three times the negative control (Burrows et al. 2016). In the case of TriMV, the multiplier may be as high as 4 in order to eliminate false positives. Compared with the survey by Burrows et al. (2009), WSMV was detected by ELISA more frequently (94\%) and TriMV $(43 \%)$ and $\mathrm{WMoV}(7 \%)$ were detected less frequently in the present study. However, the relative detection of the three viruses in the Texas High Plains remained the same (i.e., WSMV > TriMV > WMoV). Double infections of WSMV and TriMV, as well as WSMV and WMoV, and triple infections occurred less frequently than in the 2008 survey, and unlike the surveys by Burrows et al. $(2009,2016)$, this study detected no coinfections between TriMV and WMoV.

The most significant differences between the present study and previous work were revealed by qPCR analysis of samples that tested negative by the ELISA test. Many samples that tested negative by ELISA for TriMV and WMoV tested positive by the more sensitive real-time qPCR analysis-in essence, changing our understanding of virus prevalence and population structure in the Texas Panhandle. For WSMV, qPCR and ELISA results were similar, suggesting a high titer of WSMV in all infected plants. However, qPCR testing detected over twice as many positives for TriMV and over three times as many positives for WMoV. Coinfections of WSMV and TriMV remained by far the most prevalent. In this study, single infections by any of the three viruses rarely occurred, and only $5 \%$ of samples were singly infected by WSMV. TriMV and WMoV were never detected as single infections, TriMV was always found with WSMV, and $\mathrm{WMoV}$ was usually found in triple infections. WMoV was detected as a coinfection with WSMV in only $2 \%$ of samples. These results are in stark contrast to previous studies in which the incidence of single infections was much higher (Burrows et al. 2009, 2016; Byamukama et al. 2013).

The finding that most infections by mite-vectored viruses in the Texas Panhandle occurred as coinfections between WSMV and TriMV has highly significant implications for wheat farmers and breeders alike. Coinfections by WSMV and TriMV occur synergistically and result in greater symptom severity than single virus infections (Burrows et al. 2009; Byamukama et al. 2012; Tatineni et al. 2010). Since the incidence of TriMV is much higher than previously reported and coinfections between WSMV and TriMV are the norm, cultivars with resistance only to WSMV are unlikely to significantly reduce overall losses to MVVD. More importantly, such cultivars could inadvertently select for TriMV and WMoV, increasing the

Table 2. Incidence of Wheat streak mosaic virus (WSMV), Triticum mosaic virus (TriMV), and Wheat mosaic virus (WMoV) singly or in combinations in individual mites and wheat leaves collected from fields in the Texas Panhandle ${ }^{\mathrm{a}}$

\begin{tabular}{rccccccccc}
\hline & $\begin{array}{c}\text { Total } \\
\text { samples }\end{array}$ & $\begin{array}{c}\text { Overall } \\
\text { WSMV }\end{array}$ & $\begin{array}{c}\text { Overall } \\
\text { TriMV }\end{array}$ & $\begin{array}{c}\text { Overall } \\
\text { WMoV }\end{array}$ & $\begin{array}{c}\text { Only } \\
\text { WSMV }\end{array}$ & $\begin{array}{c}\text { Only } \\
\text { TriMV }\end{array}$ & $\begin{array}{c}\text { WSMV }+ \\
\text { TriMV }\end{array}$ & $\begin{array}{c}\text { WSMV + } \\
\text { WMoV }\end{array}$ & $\begin{array}{c}\text { All three } \\
\text { viruses }\end{array}$ \\
\hline Mite & 101 & 97 & 55 & 13 & 37 & 0 & 47 & 5 & 8 \\
$\%$ & & 96.0 & 54.5 & 12.9 & 36.6 & 0.0 & 46.5 & 5.0 & 7.9 \\
Leaf & 40 & 40 & 40 & 21 & 0 & 0 & 17 & 0 & 21 \\
$\%$ & & 100.0 & 100.0 & 52.5 & 0.0 & 0.0 & 42.5 & 0.0 & 52.5 \\
\hline
\end{tabular}

a Values are presented as the number of samples unless indicated otherwise. 
incidence of these in growers' fields. Although the ELISA test has value in certain circumstances, it is important for wheat breeders and research scientists to know the true nature of the mite-vectored virus population structure in the Great Plains. Epidemiological studies, research on virus population genetics, and development of superior wheat cultivars with broad resistance to MVVDs all depend on accurate diagnostics. Clearly the ELISA test should not be the only diagnostic procedure used in such studies. Testing for TriMV by conventional PCR resulted in more accurate results than those based solely on ELISA, but conventional PCR did not detect TriMV in samples with lower virus titers. It would be interesting

Table 3. Ratios of copy numbers of Wheat streak mosaic virus (WSMV) and Triticum mosaic virus (TriMV) in leaves and associated mites

\begin{tabular}{|c|c|c|c|}
\hline Leaf & Mite & $\begin{array}{c}\text { Ratio in leaf } \\
\text { (WSMV/TriMv) }\end{array}$ & $\begin{array}{c}\text { Ratio in mite } \\
\text { (WSMV/TriMV) }\end{array}$ \\
\hline $740-1$ & 1 & 52 & 2,783 \\
\hline $740-3$ & 1 & 3 & 140 \\
\hline $740-3$ & 2 & 3 & 17 \\
\hline $740-3$ & 3 & 3 & 18 \\
\hline $760-4$ & 1 & 6 & 32 \\
\hline $760-4$ & 3 & 6 & 139 \\
\hline $807-6$ & 1 & 26 & 41 \\
\hline $1836-3$ & 1 & 273 & 3 \\
\hline $1838-2$ & 1 & 3 & 508 \\
\hline $1838-2$ & 2 & 3 & 53 \\
\hline $1838-2$ & 3 & 3 & 44 \\
\hline $1838-3$ & 1 & 6 & 784 \\
\hline $1838-3$ & 2 & 6 & 158 \\
\hline $1838-3$ & 3 & 6 & 417 \\
\hline $1838-9$ & 1 & 9 & 273 \\
\hline $1838-9$ & 3 & 9 & 256 \\
\hline $1842-3$ & 1 & 2 & 31 \\
\hline $1842-3$ & 2 & 2 & 16 \\
\hline $1842-3$ & 3 & 2 & 20 \\
\hline $1869-3$ & 2 & 24 & 421 \\
\hline $1873-2$ & 1 & 14 & 57 \\
\hline $1873-2$ & 2 & 14 & 8 \\
\hline $1873-2$ & 3 & 14 & 20 \\
\hline $1879-2$ & 1 & 4 & 3 \\
\hline $1879-2$ & 2 & 4 & 5 \\
\hline $1879-2$ & 3 & 4 & 5 \\
\hline $1883-5$ & 1 & 5 & 30 \\
\hline $1883-5$ & 2 & 5 & 21 \\
\hline $1887-4$ & 2 & 107,029 & 32 \\
\hline $1891-3$ & 1 & 63,448 & 13 \\
\hline $1891-3$ & 2 & 63,448 & 65 \\
\hline $1891-3$ & 3 & 63,448 & 3 \\
\hline PDIS-26 & 1 & 11 & 244 \\
\hline PDIS-26 & 2 & 11 & 164 \\
\hline PDIS-28 & 3 & $1,223,136$ & 1,093 \\
\hline PDIS-55 & 1 & 8 & 114 \\
\hline PDIS-55 & 2 & 8 & 11 \\
\hline PDIS-55 & 3 & 8 & 13 \\
\hline PDIS-55 & 4 & 8 & 23 \\
\hline PDIS-61 & 1 & 11 & 18 \\
\hline PDIS-61 & 1 & 11 & 5 \\
\hline PDIS-61 & 1 & 11 & 60 \\
\hline PDIS-62 & 1 & 8 & 24 \\
\hline PDIS-62 & 2 & 8 & 32 \\
\hline PDIS-62 & 3 & 8 & 21 \\
\hline PDIS-82 & 1 & 4 & 10 \\
\hline PDIS-82 & 2 & 4 & 64 \\
\hline PDIS-82 & 3 & 4 & 47 \\
\hline PDIS-85 & 1 & $3,568,456$ & 15,836 \\
\hline PDIS-85 & 3 & $3,568,456$ & 20 \\
\hline PDIS-86 & 1 & 8 & 21,225 \\
\hline S3-5 & 1 & $3,248,582$ & 20 \\
\hline
\end{tabular}

to know whether the increased prevalence of TriMV, detected as coinfections with WSMV when using real-time qPCR, is unique to the Texas Panhandle wheat production region or common throughout the Great Plains. It is also interesting to speculate whether results of prior surveys would have been significantly different if qPCR had been used.

The use of qPCR in this study not only revealed a lower incidence of single infections by WSMV and a much greater incidence of TriMV than previously determined, but it also allowed a new approach for investigating host-pathogen-vector interactions. Determination of virus copy number made it possible to directly com pare titers of WSMV and TriMV in infected tillers and associated mite samples. Plants that initially tested positive for two or more viruses by ELISA were inspected for WCM but of 292 coinfected samples, only 101 mites were recovered from 40 samples. It was surprising that so few mites were present on these samples, but since they were collected later in the growing season, mite populations likely were reduced by predation or adverse environmental conditions. Although the sample number of mites was relatively low, qPCR determination of WSMV and TriMV in individual mites and the specific tiller from which they were recovered revealed interesting results. Copy numbers of WSMV and TriMV were both significantly higher in plant tissue than in mites, and the copy number of WSMV was always significantly higher than that of TriMV in plants and mites. However, and perhaps somewhat counterintuitively, the copy number ratio of WSMV/TriMV in individual mites was frequently higher than in the associated tiller (73\% of the time), but $23 \%$ of the mites had a much lower WSVM/TriMV ratio. In general, the WSMV/TriMV copy number ratio in mites was poorly correlated to the ratio in the host leaf from which the mites were collected. It appears that the WSMV/TriMV ratio in mites was in some way impacted during or after virus acquisition by the vector. Instead of the mite vector merely acquiring WSMV and TriMV in a ratio approximately equal to that found in infected plant sap, WSMV may be multiplying in the mite after acquisition, resulting in a higher copy number compared with TriMV. Alternatively, WSMV may be preferentially taken up during feeding by some WCMs, resulting in a higher WSMV/TriMV ratio, whereas others preferentially take up TriMV, resulting in a lower WSMV/TriMV ratio. Differential transmission of WSMV and TriMV by biotypes of the WCM has been reported (Hein et al. 2012; Oliveira-Hofman et al. 2015) but their potential for differential virus acquisition when feeding on coinfected plants has not been investigated. Whether these viruses multiply in the WCM is also uncertain.

In this study, the number of mites we recovered from infected plants was low. Mites were collected from tightly curled leaves and it was assumed that most had been in close association with the sampled plant for some time. However, since this was a noncontrolled field study, we did not know the cultivar from which mites were collected and it was impossible to know with any certainty whether collected mites had been on the plant for a long time or just landed. The mechanism by which the WSMV/TriMV ratio became higher or lower in the mite than in the tiller from which the mites were collected is unknown and beyond the scope of this study. However, the epidemiological implications of this observation could be significant and perhaps help explain reported differences among WCM biotypes in their ability to transmit these viruses. Likewise, the difference in incidence of TriMV and WMoV in this study may, in part, be related to differences in transmission efficiency by mite biotypes. Type 1 has been found to transmit TriMV and WMoV at a reduced rate compared with type 2 (Hein et al. 2012; McMechan et al. 2014; Oliveira-Hofman et al. 2015; Seifers et al. 2002, 2009). WCM biotypes were not determined in this study because of the limited number of mites collected and the study focus on pathogen detection and identification. However, WCM biotype 1 was reported previously from Texas (Hein et al. 2012) and is common in the Texas Panhandle (unpublished data).

\section{Acknowledgments}

We thank Jewel Arthur, Jared Bull, and Jimmy Gray for technical support. 


\section{Literature Cited}

Almas, L. K., Price, J. A., Workneh, F., and Rush, C. M. 2016. Quantifying economic losses associated with levels of wheat streak mosaic incidence and severity in the Texas High Plains. Crop Prot. 88:155-160.

Burrows, M., Franc, G., Rush, C., Blunt, T., Ito, D., Kinzer, K., Olson, J., O’Mara, J., Price, J., Tande, C., Ziems, A., and Stack, J. 2009. Occurrence of viruses in wheat in the Great Plains region, 2008. Online publication. Plant Health Prog. 10:14. doi: 10.1094/PHP-2009-0706-01-RS.

Burrows, M., Thomas, C., McRoberts, N., Bostock, R. M., Coop, L., and Stack, J. 2016. Coordination of diagnostic efforts in the Great Plains: Wheat virus survey and modeling of disease onset. Plant Dis. 100:1037-1045.

Byamukama, E., Seifers, D. L., Hein, G. L., De Wolf, E., Tisserat, N. A., Langham, M. A. C., Osborne, L. E., Timmerman, A., and Wegulo, S. N. 2013. Occurrence and distribution of Triticum mosaic virus in the central Great Plains. Plant Dis. 97:21-29.

Byamukama, E., Tatineni, S., Hein, G. L., Graybosch, R. A., Baenziger, P. S., French, R., and Wegulo, S. N. 2012. Effects of single and double infections of winter wheat by Triticum mosaic virus and Wheat streak mosaic virus on yield determinants. Plant Dis. 96:859-864.

Dhakal, S., Tan, C., Paetzold, L., Fuentealba, M. P., Rudd, J. C., Blaser, B. C., Xue, Q., Rush, C. M., Devkota, R. N., and Liu, S. 2017. Wheat curl mite resistance in hard winter wheat in the US Great Plains. Crop Sci. 57:53-61.

Friebe, B., Qi, L. L., Wilson, D. L., Chang, Z. J., Seifers, D. L., Martin, T. J., Fritz, A. K., and Gill, B. S. 2009. Wheat-Thinopyrum intermedium recombinants resistant to Wheat streak mosaic virus and Triticum mosaic virus. Crop Sci. 49:1221-1226.

Fuentes-Bueno, I., Price, J. A., Rush, C. M., Seifers, D. L., and Fellers, J. P. 2011. Triticum mosaic virus isolates in the southern Great Plains. Plant Dis. 95:1516-1519.

Graybosch, R. A., Peterson, C. J., Baenziger, P. S., Baltensperger, D. D., Nelson, L. A., Jin, Y., Kolmer, J., Seabourn, B., French, R., Hein, G., Martin, T. J., Beecher, B., Schwarzacher, T., and Heslop-Harrison, P. 2009. Registration of 'Mace' hard red winter wheat. J. Plant Regist. 3:51-56.

Haley, S. D., Johnson, J. J., Peairs, F. B., Stromberger, J. A., Heaton, E. E., Seifert, S. A., Kottke, R. A., Rudolph, J. B., Martin, T. J., Bai, G., Chen, X., Bowden, R. L., Jin, Y., Kolmer, J. A., Seifers, D. L., Chen, M., and Seabourn, B. W. 2011. Registration of 'Snowmass' wheat. J. Plant Regist. 5:87-90.

Hein, G. L., French, R., Siriwetwiwat, B., and Amrine, J. W. 2012. Genetic characterization of North American populations of the wheat curl mite and dry bulb mite. J. Econ. Entomol. 105:1801-1808.

Kumssa, T. T., Zhao, D., Bai, G., and Zhang, G. 2017. Resistance to Wheat streak mosaic virus and Triticum mosaic virus in wheat lines carrying Wsm1 and Wsm3. Eur J. Plant Pathol. 147:709-712.

Liu, W., Seifers, D. L., Qi, L. L., Friebe, B., and Gill, B. S. 2011. A compensating wheat-Thinopyrum intermedium Robertsonian translocation conferring resistance to Wheat streak mosaic virus and Triticum mosaic virus. Crop Sci. 51:2382-2390.

McMechan, A. J., Tatineni, S., and French, R. 2014. Differential transmission of Triticum mosaic virus by wheat curl mite populations collected in the Great Plains. Plant Dis. 98:806-810.

Mutti, J. S., Baenziger, P. S., Graybosch, R. A., French, R., and Kulvinder, S. G. 2011. Registration of seven winter wheat germplasm lines carrying the Wsm 1 gene for Wheat streak mosaic virus resistance. J. Plant Regist. 5:414-417.
Oliveira-Hofman, C., Wegulo, S. N., Tatineni, S., and Hein, G. L. 2015. Impact of Wheat streak mosaic virus and Triticum mosaic virus coinfection of wheat on transmission rates by wheat curl mites. Plant Dis. 99:1170-1174.

Price, J. A. 2015. Ecology and epidemiology of Wheat streak mosaic virus, Triticum mosaic virus, and their mite vector in wheat and grassland fields. Ph.D. dissertation, Texas Tech University, Lubbock.

Price, J. A., Simmons, A. R., Rashed, A., Workneh, F., and Rush, C. M. 2014 Winter wheat cultivars with temperature sensitive resistance to Wheat streak mosaic virus do not recover from early infections. Plant Dis. 98:525-531.

Price, J. A., Workneh, F., Evett, S., Jones, D. C., Arthur, J., and Rush, C. M. 2010. Effects of Wheat streak mosaic virus on root development and water-use efficiency of winter wheat. Plant Dis. 94:766-770.

Rush, C. M., and Michels, G. J., eds. 1996. Proceedings of the High Plains Disease Symposium. C\&M Press, Denver, CO.

Seifers, D. L., Harvey, T. L., Louie, R., Gordon, D. T., and Martin, T. J. 2002. Differential transmission of isolates of the High Plains virus by different sources of wheat curl mites. Plant Dis. 86:138-142.

Seifers, D. L., Harvey, T. L., Martin, T., and Jensen, T. 1997. Identification of the wheat curl mite as the vector of the High Plains virus of corn and wheat. Plant Dis. 81:1161-1166

Seifers, D. L., Martin, T. J., and Haber, S. 2013. Temperature sensitive resistance to Wheat streak mosaic virus in CO960333 and KS06HW79 wheat. Plant Dis. 97:983-987.

Seifers, D. L., Martin, T. J., Harvey, T. L., Fellers, J. P., and Michaud, J. P. 2009. Identification of the wheat curl mite as the vector of Triticum mosaic virus. Plant Dis. 93:25-29.

Seifers, D. L., Martin, T. J., Harvey, T. L., Fellers, J. P., Stack, J. P., Ryba-White, M., Haber, S., Krokhin, O., Spicer, V., Lovat, N., Yamchuk, A., and Standing, K. G. 2008. Triticum mosaic virus: A new virus isolated from wheat in Kansas. Plant Dis. 92:808-817.

Seifers, D. L., Martin, T. J., Harvey, T. L., and Haber, S. 2007. Temperature sensitive Wheat streak mosaic virus resistance identified in KS03HW-12 wheat. Plant Dis. 91:1029-1033.

Seifers, D. L., Martin, T. J., Harvey, T. L., Haber, S., and Haley, S. D. 2006. Temperature sensitivity and efficacy of Wheat streak mosaic virus resistance derived from CO960293 wheat. Plant Dis. 90:623-628.

Tatineni, S., Graybosch, R. A., Hein, G. L., Wegulo, S. N., and French, R. 2010. Wheat cultivar-specific disease synergism and alteration of virus accumulation during co-infection with Wheat streak mosaic virus and Triticum mosaic virus. Phytopathology 100:230-238.

Tatineni, S., Wosula, E. N., Bartels, M., Hein, G. L., and Graybosch, R. A. 2016. Temperature-dependent Wsm 1 and Wsm 2 gene-specific blockage of viral long-distance transport provides resistance to Wheat streak mosaic virus and Triticum mosaic virus in wheat. Mol. Plant-Microbe Interact. 29: 724-738.

Texas Small Grains Variety Trials. 2017. Texas Wheat Variety Trial Results. http:// varietytesting.tamu.edu/wheat

U.S. Department of Agriculture National Agricultural Statistics Service. 2017. Quick Stats. https://quickstats.nass.usda.gov/

Velandia, M., Rejesus, R., Jones, D. C., Price, J. A., Workneh, F., and Rush, C. M. 2010. Economic impact of the Wheat streak mosaic virus in the Texas High Plains. Crop Prot. 29:699-703. 